\title{
THE CONGRESS OF ATHENS OF 1931: METHODOLOGICAL AND TECHNICAL CONTRIBUTIONS FOR THE CONSERVATION OF ARCHITECTURAL AND ENVIRONMENTAL HERITAGE
}

\section{GENOVESE Rosa Anna ${ }^{1}$}

${ }^{1}$ prof. arch. Rosa Anna Genovese, University of Naples 'Federico II', Department of Architecture - DiARC

ABSTRACT: The Proceedings of the First International Congress of Architects and Technicians of Historic Monuments, which took place in Athens, from 21 to 30 October 1931, were published in the volume entitled La Conservation des Monuments dart et d'histoire // The Conservation of artistic and historical Monuments; a volume that represents a fundamental document to improve knowledge on the different aspects of conservation and restoration in Europe in the period between the two World Wars (1918-1940). Thus, it seems appropriate to reexamine the main contributions, which in that occasion were given by prominent European Scholars, also in order to glean useful indications for carrying out conservation, which, today more than ever, is needed to protect architectural and environmental heritage.

Firstly, it should be recalled that the 'Congress of Athens' constitutes an important pro-Europe initiative; it was, indeed, promoted by the International Museum Office of the 'International Institute of Intellectual Co-operation, a body belonging to the 'League of Nations International', to whose Assembly the congressional conclusions were in fact submitted.

Another aspect to highlight concerns how the congress works were articulated; it demonstrates the acquired awareness of how it is possible to carry out monument conservation operating based on 'General doctrines and principles' (I section) through the juridical and administrative protection, considered as 'logical deductions from doctrines and principles' (II section), on one hand, and 'technical tools' (IV, V, VI section), on the other, with restoration undertaking to enhance monuments (III section). 


\section{Rosa Anna Genovese}

\section{Principles of conservation and restoration.}

The examination of the main essays of the first Session, completed by the one on 'Administration and legislation of historical monuments' will enable us to become aware of the existing circumstances at the time, in the main European Countries (France, Italy, Great Britain, Poland, Belgium, the Netherlands) and to focus on what were the theoretical principles of conservation and restoration. The thesis expressed by Paul Léon, for France, and Gustavo Giovannoni, for Italy, emerge above all the others for their clarity. I intend to review them also by examining the texts they submitted to the 'Congress of Athens'.

\section{Monument environment.}

The need to enhance monuments, in the sense of mise en valeur on an aesthetic level and, thus, carry out their aesthetic enhancement, intending them as works of art, and not merely increase their social and economic value, as assets, led to take into consideration, for the purposes of conservation, the space surrounding the monument, to which a Session of the Congress was indeed dedicated.

The testimony of a character such as Victor Horta appears interesting in relation to this topic. His essay for the 'Congress of Athens' shows consideration for the urban space immediately surrounding the monument, striving to define the fundamental elements of a theory.

Arising from the aforementioned important scientific contributions supplied during the Congress, the official conclusions of the 'Conference of Athens' were the source of the text of the Athens Charter.

KEY WORDS: restoration of monuments, Monument environment, International documentation, Technical and moral co-operation 
The Proceedings of the First International Congress of Architects and Technicians of Historic Monuments, which took place in Athens, from 21 to 30 October 1931, were published in the volume entitled La Conservation des Monuments d'art et d'histoire // The Conservation of artistic and historical Monuments; a volume that represents a fundamental document to improve knowledge on the different aspects of conservation and restoration in Europe in the period between the two World Wars (1918-1940). Thus, it seems appropriate to reexamine the main contributions, which in that occasion were given by prominent European Scholars, also in order to glean useful indications for carrying out conservation, which, today more than ever, is needed to protect architectural and environmental heritage ${ }^{1}$.

Firstly, it should be recalled that the 'Congress of Athens' constitutes an important pro-Europe initiative; it was, indeed, promoted by the International Museum Office of the 'International Institute of Intellectual Co-operation, a body belonging to the 'League of Nations International', to whose Assembly the congressional conclusions were in fact submitted ${ }^{2}$.

Another aspect to highlight concerns how the congress works were articulated; it demonstrates the acquired awareness of how it is possible to carry out monument conservation operating based on 'General doctrines and principles' (I section) through the juridical and administrative protection, considered as 'logical deductions from doctrines and principles' (II section), on one hand, and 'technical tools' (IV, V, VI section), on the other, with restoration undertaking to enhance monuments (III section).

\section{Principles of conservation and restoration}

The examination of the main essays of the first Session, completed by the one on 'Administration and legislation of historical monuments' will enable us to become aware of the existing circumstances at the time, in the main European Countries (France, Italy, Great Britain, Poland, Belgium, the Netherlands) and to focus on what the theoretical principles of conservation and restoration were. The thesis expressed by Paul Léon, for France, and Gustavo Giovannoni, for Italy, emerge above all the others for their clarity. I intend to review them also by examining the texts they submitted to the 'Congress of Athens'.

After brilliantly revisiting the history of the principles, methods and Services of protection, relative to conservation and restoration in France, Paul Léon highlights the clear relationship existing between Restoration and History first, then between Restoration and History of Art,

\footnotetext{
${ }^{1}$ Giovannoni G., La Conferenza internazionale di Atene pel restauro dei monumenti, [in:] Bollettino d'Arte del Ministero dell'Educazione Nazionale, Fasc. IX, Rome, 1932.

${ }^{2}$ Hautecoeur L. E. G., Conférence internationale d'experts pour la protection et la conservation des monuments d'art et d'histoire, [in:] Gazette des Beaux Arts, Paris, 1932.

${ }^{3}$ Genovese R. A., La Conferenza di Atene (1931): alcuni contributi metodologici e tecnici, [in:] R. A. Genovese (ed.), Note in materia di Conservazione e Restauro dei monumenti, Arte Tipografica, Napoli, 1996, pp. 9-56.
} 
and finally records the definitive passage from Restoration to Conservation. Thus, he illustrates the features of restoration activity, stressing, also, the fundamental contribution arising from the most recent technical breakthroughs.

"The restoration of monuments - Paul Léon states in Athens - does not date back, in France, but one century. It was born on the ruins left by the revolution and it reached its centenary on the ones of the world war. The doctrines that guided it vary according to the epochs, purposes, means of action. With the occurrence of such different cases, dissimilar issues, one must guard oneself against establishing principles that are too strict or too absolute rules.

And he ends "... It is a singular paradox that modern architecture, clearly breaking, due to the universal use of polished and coated materials, from the ancient and traditional building by foundation and re-foundation, has so powerfully helped the conservation of our ancient monuments, to which it is, by principle, radically extraneous and which it is destined to replace in the future. While one hundred years ago the favour of a fleeting fashion had brought back to appraisal the imitation of the Middle Ages, opposing, we saw it, in sterile controversies, builders and restorers; the dispute of ancients and moderns is nowadays over, the proscription or idolisation of styles. The scrupulous conservation of all the arts of the past aligns with the freedom of research of the present. Yet, while in the last century, ancient and modern architecture, derived from the same principles, had been able to collaborate in the creation of workshops, building yards and artisans, now that quarries are shutting down, that decorators, stone cutters, carpenters, sculptors are becoming rarer every day, the restoration of historic monuments, although supplied with legislative, financial, technical means that are more effective than ever, is impoverished in its possibilities, threatened in its future and a little isolated within the architecture of its time. More favourable to works of strict conservation than to great restoration work, the current epoch will mark, for our French Monuments, a period of survival rather than resurrection; but maybe it is, for this very reason, notwithstanding the illustrious word of Michelet, more akin to the truth and more faithful to history."

The speech uttered by Gustavo Giovannoni in Athens, can be considered, not only a fundamental document for the discipline of 'Restoration', but also an extremely stimulating one, to this day, for the cultural and social debate on the subject.

After having drawn attention to the peculiarities of the issues of restoration in Italy, he illustrates the extension of the concept of monument to what he defined as 'secondary works' and, more broadly, to the ancient parts of cities. This is an extension that involves a new vision of the relationship between Restoration and Urban Planning, especially concerning the safeguard of historic centres.

After shedding light on the organisation of the Italian Protection Services, Giovannoni focuses on the analysis of the restoration theories dominant at the time, developed by Camillo Boito. He first highlights the main points of view that such theories rest on, which, according to him, are three: of the leaned man, of the architect and of the simple citizen. Referring, then, to the practice of the activity of restoration, he defines, through a brief historic analysis, the criteria on which such activity was based, and still is based, with the purpose, as he states, of 'conserving monuments'. 
Among such criteria, Giovannoni indicates as relevant the one that "intends to distinguish the added elements from the original ones, in order to not create artistic falsehoods and to not mislead scholars". This also stands for cases of integration, but he states again - thus letting transpire his disapproval towards modern architecture, of which he saw the expressions around him - that this will only be correctly accomplished in the future "when modern architecture will have left behind this period we are going through, an indecisive epoch of fleeting fashions".

In a second speech at the Congress, Giovannoni reports on the "modern means of construction applied to the restoration of monuments", taking time to deal specifically with the application of construction techniques in the field of restoration for both the purposes of completion and reintegration, coming to the conclusion that all modern means possible should be applied to restoration; although this should be done with caution and balance.

Giovannoni then supplies a series of examples of interventions, including some carried out with the use of structures of reinforced concrete. He finishes by mentioning the case of the ships of Nemi and of the tower of Pisa, which requires the contribution of many, different disciplinary fields to achieve the restoration project.

This document was followed, during the Congress, by other reports illustrating cases of restoration executed. Amedeo Maiuri, in the archaeological field, referred of the digs of Herculaneum, after having mentioned the work that, especially in those years, had been carried out in Pompeii "where the tendency was to recover the integral appearance of the buildings found, so that every house, small shop, warehouse, would offer the visitor a complete picture... so that he may, without effort, reconstruct, at every step, the life and the atmosphere of the ancient city.. Concerning the conservation of the mural frescos, Maiuri expressed his worries and stated that he awaited the help of physical and chemical science "to be able to move from an empirical state, in the methods of protection and conservation, to a rational and scientific treatment" and eliminate all causes of deterioration, alteration and fading of colour on mural paintings.

Gino Chierici later reported extensively, again on the interventions operated on the architectural heritage of Region Campania, describing restorations he conducted, from 1925 onwards, on monuments of: Paleochristian Architecture (baptistery of Nocera, church of S.Giovanni in Cimitile, S.Gennaro extra moenia in Naples, the small basil of Prata); Lombard Architecture (church of S.Salvatore a Corte in Capua); Byzantine Architecture (S.Costanzo in Capri, S.Giovanni a mare in Gaeta); Benedictine Architecture (S.Angelo in Formis, SS.Annunziata in Ventaroli, at Carinola, cloister of S.Sofia in Benevento); Norman Architecture (cathedral of Salerno, S.Pietro alli marmi in Eboli, cathedral of Casertavecchia); Gothic Architecture (Tower of Federico II in Capua, Certosa di San Costanzo in Capri, S.Domenico in Gaeta, S.Pietro in Teggiano, SS.Annunziata in Minturno and in the city of Naples: church of S.Lorenzo, church of S.Pietro a Maiella, church and convent of S. Chiara, the 14th Century church of S.Maria Donnaregina, church of Incoronata, churches of S. Maria Succurre Miseris).

In another essay Gino Chierici illustrated, later during the Congress, some technical details of restorations carried out on some of the aforementioned Neapolitan Monuments. He also referred on the widespread use of the masterful craft of scucitura e cucitura (un-sewing and sewing) in the 


\section{Rosa Anna Genovese}

consolidation of tufa masonry and on the use of reinforced concrete that "can be of great help in monument conservation, provided that it is used with discretion and only when other systems cannot be applied".

\section{Monument environment}

The need to enhance monuments, in the sense of mise en valeur on the aesthetic level and, thus, carry out their aesthetic enhancement, intending them as works of art, and not merely increase their social and economic value, as assets, led to take into consideration, for the purposes of conservation, the space surrounding the monument, to which a Session of the Congress was indeed dedicated.

The environment subjected to conservation and restoration appears, yet, at the time, the one closely surrounding the architectural work of outstanding value, the monument of notable historic-artistic interest, which is and remains the focus of the conservation operation.

We are still far from seeing a widespread acceptance of the modern notion (stated later in the Venice Charter of 1964) of urban environment to be protected, of a complex of values of minor architectures that, in the absence of a masterpiece of art, attest to a particular moment in the evolution of civilisation.

The testimony of a character such as Victor Horta appears interesting in relation to this topic. His essay for the 'Congress of Athens' shows consideration for the urban space immediately surrounding the monument, striving to define the fundamental elements of a theory $y^{4}$.

He stresses that "the surroundings of a monument feature three essential elements:

1) the empty space between the monument and its actual surroundings;

2) the surroundings made up of utilitarian or decorative buildings;

3) the boundaries of the surroundings, such as the public streets giving access to them."

The surroundings of monuments - he adds - are a complex matter, which gives rise numerous and difficult issues; he then suggests to profit more often from the marvellous examples that were left behind by the 'Masters of the past'. As for the role of green areas surrounding monuments, Victor Horta remarks that "this important decorative element has seldom been employed wisely over the last century. Certainly greenery, plantations, constitute an infinitely interesting accessory, but in most cases in which the architectural surroundings no longer exist, vegetation distributed in such a way as to recall the masses now missing, could supply an agreeable solution." ${ }^{5}$

${ }^{4}$ Horta V., Les applications de l'Urbanisme à l'entourage des monuments, Bruxelles, 1923.

${ }^{5}$ Borsi F., Portoghesi P., Victor Horta, Rome, $1969 .$. 
The essay of Horta was followed by the one of Giogio Nicodemi, Historic-Artistic Superintendent of the City Council of Milan, who emphasised, in Athens, the importance of considering not the environment of a single monument, as presented by Victor Horta, but the 'environment of monuments' considered as a whole. Only after having guaranteed the conservation of such overall values and meanings, Nicodemi stated, it is possible to think of acting to restore a single monument and the environment closely surrounding it.

Antonio Muñoz, Director of Antiquities and Fine Arts of the City Council of Rome, dealt with the problem of intervening in historic centres and the relationship between ancient and new, linking his speech to the case of Rome and posing the question of how to harmonise ancient buildings with the modern environment.

Completing the Session of the Congress, dedicated to the study of the criteria and methods apt to highlight the aesthetic value of monuments, two essays were then illustrated (one by the Italian Lensi, the other by the Greek Oikonomos) that stressed, especially, the existing relationship between architectural heritage and natural heritage and the possibility of employing vegetation to improve the ambient surrounding monuments.

\section{The legislation in Italy before the Conference of Athens.}

The general picture excellently supplied by Gustavo Giovannoni was completed during the Conference by the reports on legislative and juridical aspects presented by Francesco Pellati (Superior Inspector of Fine Arts) and by Rodolfo Micacchi (Superintendent of monuments of Tripolitania).

After the 'Conference of Athens' and the issuing of the 'Italian Charter of Restoration' // Carta Italiana del Restauro (1932), Italy adopted, in 1939, more modern Laws of protection (the n.1089 of 1 June, on the 'Protection of things of Artistic or Historic interest', and the n. 1497 of 29 June, on the 'Protection of natural beauties') which in later years would be integrated by new measures reflecting the more current requirements of the culture of conservation, such as the 'Code of cultural and landscape heritage' // Codice dei beni culturali e del paesaggio (2004).

The following seven important 'Resolutions', called 'Restoration Charter', arose from the aforementioned scientific contributions supplied during the Congress:

1. International organizations for the Restoration of historic monuments on operational and advisory levels are to be established.

2. Proposed Restoration projects are to be subjected to knowledgeable criticism to prevent mistakes, which may cause loss of character and historical values to the monuments.

3. Problems of preservation of historic sites are to be solved by legislation at national level for all Countries.

4. Excavated sites which are not subject to immediate restoration should be reburied to ensure their protection. 
5. Modern techniques and materials may be used in restoration work.

6. Historical sites must be guarded by a strict protection system.

7. Special attention should be given to the protection of areas surrounding historic sites.

These Resolutions, presented by the architects and technicians of Restoration, led to the following 'General Conclusions', from which, in turn, the text of the arose, thus articulated:

I. Doctrines, General Principles;

II. Administrative and legislative measures regarding historic monuments;

III. Enhancement of ancient monuments;

IV. Restoration of monuments;

$\mathrm{V}$. The deterioration of monuments;

VI. The technique of Conservation;

VII. The Conservation of monuments and International Collaboration.

Concerning point VII in particular, the Conference recommended to respect the character and physiognomy of the city in the construction of buildings, especially nearby ancient monuments, where the environment must be the object of special care. The same respect is due to some particularly picturesque viewpoints.

Plantations and ornamental vegetation apt to certain groups of monuments for the conservation of their ancient character may also be considered objects of study.

The Congress also recommended the implementation of:

a. technical and moral co-operation among Countries for the conservation of the artistic and archaeological heritage of humanity;

b. the role of education in the respect of monuments;

c. the value of an international documentation.

Concerning point VII c, the Congress issued a vote so that:

1. each Country, or the Institutions created or recognised competent for this purpose, publish an inventory of ancient monuments, with photographs and explanatory notes;

2. each Country constitute an Archive, which shall contain all documents relating to its historic monuments;

3. the International Museum Office include in its publications the studies on the procedures and methods of conservation of historic monuments;

4. such Office study the best means of sharing and utilising the information and architectural, historic and technical data. 


\section{Bibliography}

AA.VV. , The Proceedings, edited by the 'Office international des Musées', of the Institute for Intellectual Cooperation of Paris, [in:] La Conservation des Monuments d'art et d' histoire / The Conservation of artistic \& historical Monuments, Paris, 1933.

Borsi F., Portoghesi P., Victor Horta, Rome, 1969.

Genovese R. A., La Conferenza di Atene (1931): alcuni contributi metodologici e tecnici, [in:] R. A. Genovese (ed.), Note in materia di Conservazione e Restauro dei monumenti, Arte Tipografica, Napoli, 1996, pp. 9-56.

Giovannoni G., La Conferenza internazionale di Atene pel restauro dei monumenti, [in:] Bollettino d'Arte del Ministero dell'Educazione Nazionale, Fasc. IX, Rome, 1932.

Hautecoeur L. E. G., Conférence internationale d'experts pour la protection et la conservation des monuments d'art et d'histoire, [in:] Gazette des Beaux Arts, Paris, 1932.

Horta V., Les applications de l'Urbanisme à l'entourage des monuments, Bruxelles, 1923. 